\title{
Pelatihan Pemantauan Pertumbuhan Balita sebagai Upaya Deteksi Dini Stunting
}

\author{
Atika Nur Azizah $^{1}$, Khamidah Achyar ${ }^{2}$ \\ ${ }^{1,2}$ Program Studi S1 Kebidanan \\ Universitas Muhammadiyah Purwokerto \\ Email : atikanurazizah@ump.ac.id
}

\begin{abstract}
Abstrak
Upaya peningkatan status gizi masyarakat termasuk penurunan prevalensi balita pendek menjadi salah satu prioritas pembangunan nasional yang tercantum di dalam sasaran pokok Rencana Pembangunan jangka Menengah Tahun 2015 - 2019. Pemantauan pertumbuhan balita merupakan salah satu upaya yang dilakukan sebagai deteksi dini kejadian stunting. Tujuan pengabdian ini yaitu meningkatkan pengetahuan dan keterampilan tentang deteksi dini stunting melalui pemantauan pertumbuhan balita. Metode yang digunakan dalam pengabdian ini meliputi beberapa tahap yaitu metode ceramah, FGD (Focus Group Discussion), dan praktik membuat tikar pertumbuan sebagai alat pemantauan pertumbuhan balita dalam deteksi dini stunting. Subjek dalam pengabdian ini yaitu anggota daerah Nasyiatul Aisyiyah Banyumas yang memiliki balita sebanyak 57 orang yang bertempat di Majelis Ta'lim Muhammadiyah Cabang Purwojati, Kabupaten Banyumas. Hasil adanya peningkatan pengetahuan baik sebesar 75,4\%. Simpulannya bahwa pelatihan pemantauan pertumbuhan balita dapat meningkatkan pengetahuan dan keterampilan sebagai upaya deteksi dini kejadian stunting.
\end{abstract}

Kata Kunci: pemantauan pertumbuhan balita, stunting

\begin{abstract}
Efforts to improve the nutritional status of the community, including reducing the prevalence of short children, are among the national development priorities listed in the main targets of the 2015-2019 Medium-term Development Plan. Monitoring of toddler growth is one of the efforts undertaken as early detection of stunting events. The purpose of this service is to increase knowledge and skills regarding early detection of stunting through monitoring the growth of toddlers. The method used in this service includes several stages, namely the lecture method, FGD (Focus Group Discussion), and the practice of making a mat for growth as a toddler growth monitoring tool in early detection of stunting. The subjects in this service are 57 members of the Nasyiatul Aisyiyah Banyumas area who are housed in the Majelis Ta'lim Muhammadiyah of Purwojati, Banyumas Regency. The results of an increase in good knowledge by $75.4 \%$. The conclusion is that toddlers growth monitoring training can improve knowledge and skills as an effort to detect stunting events early.
\end{abstract}

Keywords: monitoring of toddler growth, stunting

\section{PENDAHULUAN}

Upaya peningkatan status gizi masyarakat termasuk penurunan prevalensi balita pendek menjadi salah satu prioritas pembangunan nasional yang tercantum 
di dalam sasaran pokok Rencana Pembangunan Jangka Menengah Tahun 2015 2019. Target penurunan prevalensi stunting (pendek dan sangat pendek) pada anak baduta (dibawah 2 tahun) adalah menjadi 28\% (Bappenas, 2014).

Menurut Keputusan Menteri Kesehatan No.1995/MENKES/SK/XII/2010 tentang Standar Antropometri Penilaian Status Gizi Anak, pengertian pendek dan sangat pendek adalah status gizi yang didasarkan pada indeks Panjang Badan menurut Umur $(\mathrm{PB} / \mathrm{U})$ atau Tinggi Badan menurut Umur $(\mathrm{TB} / \mathrm{U})$ yang merupakan padanan istilah stunted (pendek) dan severely stunted (sangat pendek). Balita pendek (stunting) dapat diketahui bila seorang balita sudah diukur panjang atau tinggi badannya, lalu dibandingkan dengan standar, dan hasilnya berada di bawah normal. Balita pendek adalah balita dengan status gizi yang berdasarkan panjang atau tinggi badan menurut umurnya bila dibandingkan dengan standar baku WHO MGRS (Multicentre Growth Reference Study) tahun 2005, nilai z-scorenya kurang dari -2SD dan dikategorikan sangat pendek jika nilai z-scorenya kurang dari -3SD (Kemenkes, 2016).

Masalah balita pendek menggambarkan adanya masalah gizi kronis, dipengaruhi dari kondisi ibu/calon ibu, masa janin, dan masa bayi/balita, termasuk penyakit yang diderita selama masa balita. Seperti masalah gizi lainnya, tidak hanya terkait masalah kesehatan, namun juga dipengaruhi berbagai kondisi lain yang secara tidak langsung mempengaruhi kesehatan. Persentase balita (usia 0-59 bulan) menurut status gizi dengan indeks Tinggi Badan/Umur di Provinsi Jawa Tengah tahun 2016 sebesar 17,78\% naik pada tahun 2017 sebesar 20,60\%. Berdasarkan data riskesdas tahun 2018 terdapat 30,8\% balita dengan kriteria sangat pendek dan pendek. Kriteria sangat pendek yaitu 11,5\% dan kriteria pendek 19,3\% naik dibandingkan tahun 2016 yaitu sebesar 17,78\%. Hal tersebut menunjukkan bahwa setiap tahun terjadi peningkatan balita pendek dan sangat pendek di Indonesia (Kemenkes RI, 2018).

Mitra kami yaitu Nasyiatul Aisyiyah Daerah Banyumas merupakan Nasyiatul Aisyiyah yang menjadi inspirasi bagi Nasyiatul Aisyiyah Cabang di Banyumas. Banyumas yang terdiri dari 27 kecamatan sehingga terdapat 27 Nasyiatul Aisyiyah Cabang. Pengurus dan anggota Nasyiatul Aisyiyah paling dominan merupakan ibu-ibu muda yang memiliki balita. Tentunya setiap ibu 
menginginkan pertumbuhan balitanya normal. Berdasarkan hasil observasi dan wawancara dengan mitra, mitra sangat membutuhkan pelatihan dalam deteksi dini stunting pada anak balita. Fenomena stunting yang berkembang di Indonesia juga membuat khawatir ibu-ibu Nasyiatul Aisyiyah di Kabupaten Banyumas sehingga muncul ide untuk melakukan pelatihan Pemantauan Pertumbuhan Balita (PPG) untuk deteksi dini stunting.

Ada sebuah inovasi dalam mencegah stunting yaitu dengan tikar pertumbuhan (Length Mat). Tikar Pertumbuhan memberikan petunjuk visual bagi petugas kesehatan dan orang tua, untuk melihat apakah anak memiliki tinggi yang sesuai usia mereka. Pada tikar terdapat ukuran yang berbeda antara anak-anak perempuan dan laki-laki. Tikar ini dipakai oleh posyandu untuk mendeteksi stunting secara dini dan secara cepat mengidentifikasi anak-anak yang memerlukan perhatian khusus. Hal inilah yang menjadi dasar pertimbangan untuk mengadakan kegiatan pengabdian kepada Nasyiatul Aisyiyah Daerah Banyumas dalam Pelatihan Pemantauan Pertumbuhan Balita (PPG) sebagai upaya deteksi dini stunting.

\section{MASALAH}

Berdasar analisis situasi diatas permasalahannya adalah :

1) Mitra belum mengetahui pengetahuan tentang pemantauan pertumbuhan balita dan stunting.

2) Mitra belum mengetahui cara deteksi dini stunting.

\section{METODE}

\section{1) Model Pengabdian}

Metode yang digunakan ceramah dan tanya jawab. Media pembelajaran yang digunakan meliputi LCD proyektor . Sebelum acara, dilakukan pre-test terlebih dahulu berupa kuesioner kepada peserta untuk mengetahui pengetahuan tentang deteksi dini stunting. Setelah selesai pemaparan, maka peserta dilakukan post test. Selanjutnya dilakukan praktik pembuatan tikar pertumbuhan dan diikuti oleh seluruh perwakilan cabang Nasyiatul Aisyiyah sehingga dapat menjadi contoh dalam penerapan deteksi dini stunting di cabangnya masing-masing. 
2) Tempat Kegiatan Pengabdian

Kegiatan pengabdian dilaksanakan di Majelis Ta'lim Muhammadiyah Cabang Purwojati, Kabupaten Banyumas.

\section{HASIL DAN PEMBAHASAN}

1) Hasil

Hasil kuesioner pengetahuan peserta pelatihan tentang deteksi dini stunting berdasarkan hasil pre test dan post test menunjukkan antusias yang sangat baik oleh peserta. Hal tersebut dapat diketahui berdasarkan hasil di bawah ini :

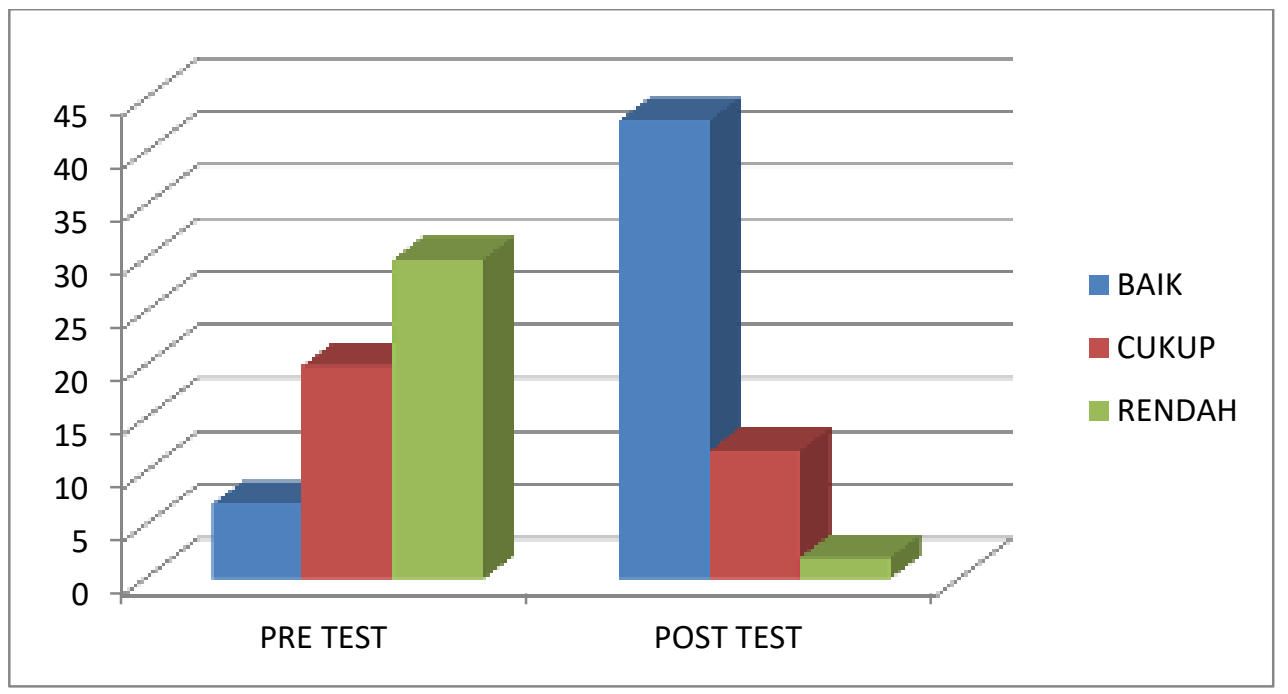

Diagram 1. Pretest-Posttest Pengabdian

Berdasarkan diagram di atas menunjukkan peningkatan pengetahuan peserta pada saat pre test terbanyak memiliki pengetahuan baik sebesar $12,3 \%$ ( 7 peserta) dan saat post test meningkat menjadi 75,4\% (43 peserta). 

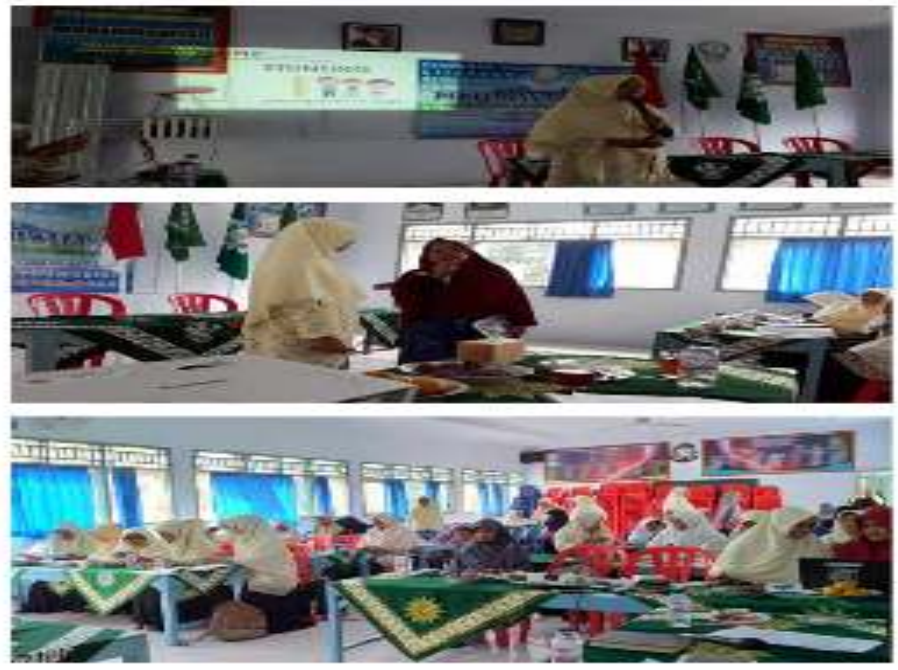

Gambar 1. Pelatihan Pemantauan Pertumbuhan Balita

Selanjutnya melakukan praktik pembuatan tikar pertumbuhan yang dilakukan oleh seluruh peserta berdasarkan dengan cabang masing-masing Nasyiatul Aisyiyah.
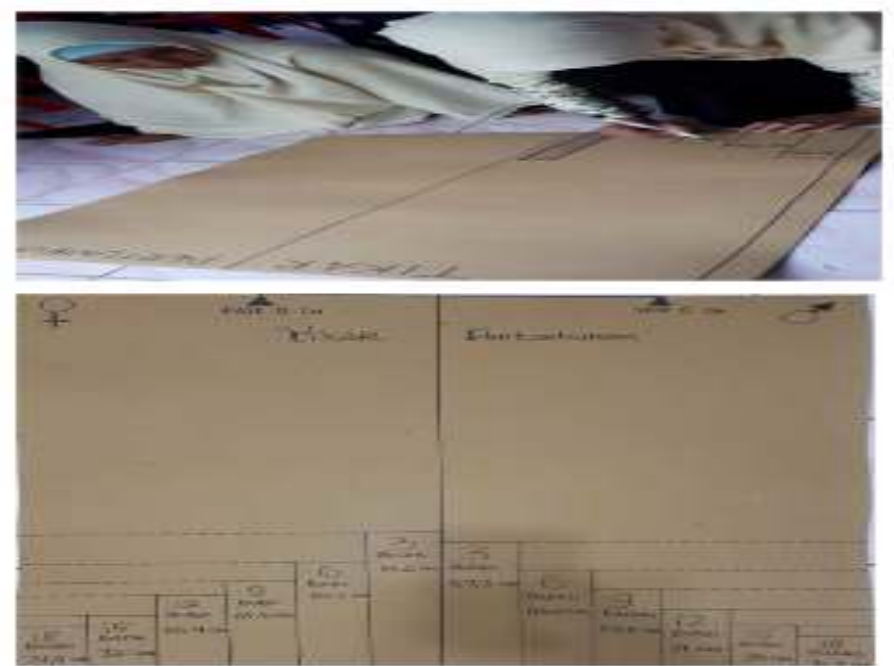

Gambar 2. Praktik Pembuatan Tikar Pertumbuhan

Pada keterampilan pembuatan Tikar Pertumbuhan, didapatkan hasil sebagai berikut : 


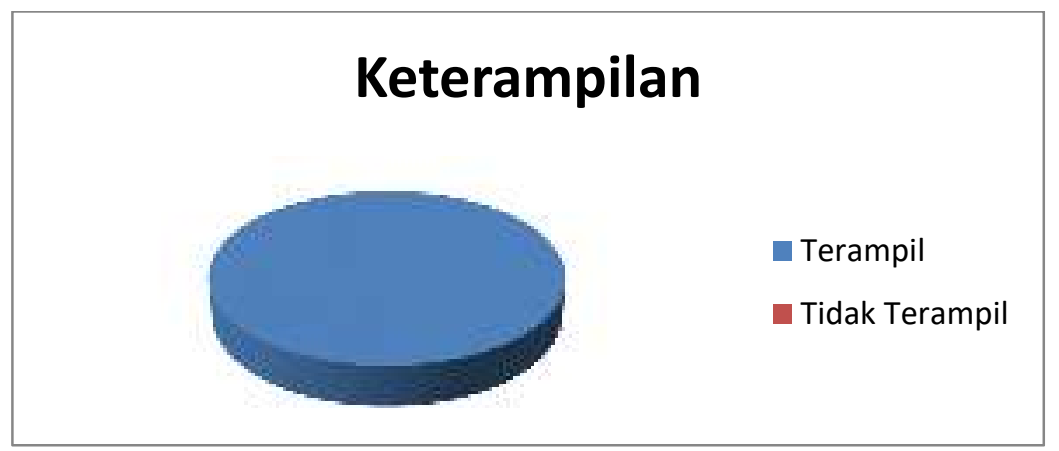

Diagram 2. Hasil Keterampilan Praktik Pembuatan Tikar Pertumbuhan

Berdasarkan hasil diagram di atas menunjukkan semua peserta terampil membuat tikar pertumbuhan yang telah disimulasikan oleh narasumber. Peserta yang membuat tikar pertumbuhan dilakukan secara kelompok setiap cabang nasyiatul aisyiyah sehingga setiap cabang mendatangkan 2-3 peserta dan terdapat 27 kelompok.

\section{2) Pembahasan}

Tikar Pertumbuhan memberikan petunjuk visual bagi petugas kesehatan dan orang tua, untuk melihat apakah anak memiliki tinggi yang sesuai usia mereka. Pada tikar terdapat ukuran yang berbeda antara anak-anak perempuan dan lakilaki. Tikar ini dipakai oleh posyandu untuk mendeteksi stunting secara dini dan secara cepat mengidentifikasi anak-anak yang memerlukan perhatian khusus (Kemendes, 2018).

Pelatihan merupakan suatu bentuk bantuan dalam proses pembelajaran yang terorganisir dan sistematis dengan jangka waktu yang relatif singkat untuk meningkatkan pengetahuan dan keterampilan peserta pelatihan yang sifatnya praktis guna mencapai tujuan tertentu ( Kamil, 2010)

Semakin dekat kebutuhan program pelatihan bersentuhan dengan kebutuhan/ pelaksanaan pekerjaan, maka akan semakin cepat seseorang untuk belajar menguasai pekerjaan tersebut. Dengan kata lain, pengalihan pengetahuan dan keterampilan bisa terjadi karena penerapan teori dalam situasi yang nyata atau karena praktek yang bersifat simulasi. Artinya pengetahuan dan keterampilan yang diperoleh dalam simulasi dapat dengan mudah dialihkan dalam situasi sebenernya. (William B. Werther dalam Skripsi Yusuf Husaeni, 2013)

Evaluasi psikomotor peserta masih belum percaya diri dalam membuat dan mempraktekkan kepada balita karena baru pertama kali mencoba. Diperlukan 
usaha rutin setiap bulan untuk mempraktikkan penggunan tikar pertumbuhan sehingga bisa menjadi alat deteksi dini stunting yang dapat bermanfaat bagi balita di wilayah Kabupaten Banyumas.

\section{SIMPULAN}

Pengabdian kepada masyarakat sebagai bentuk pelatihan pertumbuhan balita sebagai deteksi dini kejadian stunting mendapatkan banyak manfaat seperti peningkatan pengetahuan peserta pelatihan dari $12,3 \%$ pengetahuan baik menjadi $75,4 \%$ dan $100 \%$ peserta mampu membuat tikar pertumbuhan hasil kerja secara berkelompok.

\section{DAFTAR PUSTAKA}

Badan Perencanaan Pembangunan Nasional (Bappenas). 2014. Rencana Pembangunan Jangka MenengahNasional (RPJMN) 2015-2019. Jakarta.

Kamil, M. 2010. Model Pendidikan dan Pelatihan. Bandung: Alfabeta

Kementerian Desa, Pembangunan Daerah Tertinggal, dan Transmigrasi. 2018. Buku Saku Kader Pembangunan Masnusia (KPM) Memastikan Konvergensi Penanganan Stunting Desa. Kemendes : Jakarta.

Kementerian Kesehatan RI. 2016. Situasi Balita Pendek. Jakarta : Kemenkes RI.

Kementerian Kesehatan RI. 2018. Data dan Informasi Profil Kesehatan Indonesia 2017. Jakarta : Kemenkes RI.

Mitayani, Sartika W. 2010. Buku Saku Ilmu Gizi. Jakarta: Trans Info Media.

Pambudi J, Christijani R. 2017. Praktek Penyapihan Dini serta Huungannya dengan Keadaan Sosial Ekonomi dan Wilayah Tempat Tinggal. Penelitian Gizi dan Makanan: Desember Vol.40(2): 87-94.

Proverawati A, Wati EK. 2010. Ilmu Gizi Untuk Keperawatan dan Gizi Kesehatan. Yogyakarta : Muha Medika.

Riskesdas. 2018. Hasil Utama Riskesdas 2018. Kementerian Kesehatan Badan Penelitian dan Pengembangan Kesehatan : Jakarta

Werther, William B, dan Keith Davis dalam Tb. Sjafri Mangkuprawira. 2013. Human Resources and Personnel Management. Fifth Edition. New York: McGraw-Hill, Inc 